\title{
Preparation and Characterization of Flexible Poly(vinyl chloride) Foam Films
}

\author{
E. Şahin, F. Y. Mahlicli, S. Yetgin, D. Balköse \\ Department of Chemical Engineering, Izmir Institute of Technology, Urla 35430, Izmir, Turkey
}

Received 3 September 2010; accepted 20 September 2011

DOI 10.1002/app.35681

Published online 14 January 2012 in Wiley Online Library (wileyonlinelibrary.com).

\begin{abstract}
In this study, the effect of activator $\mathrm{ZnO}$ and heating time at $190^{\circ} \mathrm{C}$ on foaming, gelation, and dehydrochlorination of poly(vinyl chloride) (PVC) plastisol was investigated. For this purpose, a PVC plastisol was prepared by mixing $\mathrm{PVC}$, dioctyl phthalate (DOP), azodicarbonamide (ADC), $\mathrm{ZnO}$, and the heat stabilizers calcium stearate $\left(\mathrm{CaSt}_{2}\right)$ and zinc stearate $\left(\mathrm{ZnSt}_{2}\right)$. PVC plastisol films were heated for $3,6,12$, and 24 min periods at $190^{\circ} \mathrm{C}$ to see the effect of heating time on the gelation and foaming processes of the PVC foam. The time of $12 \mathrm{~min}$ was determined to be optimum for the completion of gelation and foaming processes without thermal degradation of PVC. No foaming was observed under the same conditions for the samples without $\mathrm{ZnO}$. $\mathrm{ZnO}$ had a significant catalytic effect on ADC decomposition, accelerating the
\end{abstract}

foaming of the films. Average porosity measurement showed a consistent increase in porosity with heating time up to $76 \%$ and the average density decreased from 1.17 to $0.29 \mathrm{~g} / \mathrm{cm}^{3}$ on foaming. Tensile tests showed that the tensile strength and tensile strain both increased considerably up to $0.98 \mathrm{MPa}$ and $207 \%$, respectively, with heating time and the elastic modulus was seen to gradually decrease from 4.7 to $0.7 \mathrm{MPa}$ with heating time. Films without $\mathrm{ZnO}$ had higher tensile strength since there were no pores. PVC thermomat tests showed that $\mathrm{ZnO}$ lowered the stability time of plastigel film with azodicarbonamide. (C) 2012 Wiley Periodicals, Inc. J Appl Polym Sci 125: 1448-1455, 2012

Key words: PVC plastisols; foaming; azodicarbonamide; zinc oxide; films

\section{INTRODUCTION}

Polymeric foams are extensively used in furniture, transportation, bedding, carpet underlay, packaging, textiles, toys, gasket, sport applications, and insulation appliances with the properties of lightweight, excellent strength/weight ratio, superior insulating abilities, and energy absorbing performance and comfort features. Clear, colorable, and nontoxic polymer polyvinylchloride (PVC) could also be used for preparing polymeric foams. ${ }^{1,2}$

In the preparation of PVC foams, PVC resin is dispersed with a suitable plasticizer, stabilizer, and blowing agent and heated to $180-200^{\circ} \mathrm{C}$ for simultaneous gelation and foaming of the plastisol. ${ }^{2}$ In addition, degradation also takes place during PVC foam processing starting at about $100^{\circ} \mathrm{C}$ by autocatalysis of the evolved hydrogen chloride. ${ }^{3}$ The dehydrochlorination of PVC gives hydrogen chloride and dePVC having conjugated double bonds as shown in eq. (1).

$$
\mathrm{PVC}(\mathrm{s}) \rightarrow \operatorname{dePVC}(\mathrm{s})+\mathrm{HCl}(\mathrm{g})
$$
tr).

Correspondence to: D. Balköse (devrimbalkose@iyte.edu.

Journal of Applied Polymer Science, Vol. 125, 1448-1455 (2012) (C) 2012 Wiley Periodicals, Inc.
Various organic and inorganic compounds are used as heat stabilizers against degradation processes including synergistic metal soaps $\mathrm{CaSt}_{2}$ and $\mathrm{ZnSt}_{2}{ }^{4}$ metal soaps and zeolites, ${ }^{5}$ metal soaps and epoxidized soybean oil. ${ }^{6}$

Both flexible and rigid PVC foams have been prepared by adding the blowing agent azodicarbonamide (ADC) to PVC plastisol. ${ }^{1,2}$ ADC is known to promote foam formation by decomposing at 195$216^{\circ} \mathrm{C}$ depending on the mode of preparation and releasing a large volume of nitrogen, carbon monoxide, and cynic acid gases as reported by Garcia and Macilla. ${ }^{3}$ Solid residues urazol and hydroazodicarbonamide were also formed by ADC decomposition. Finely dispersed filler additives are known to reduce the decomposition temperature by activating ADC and providing nucleation sites for gas evolution. ${ }^{7}$ ADC decomposition kinetics at $500 \mathrm{~K}$ was investigated by Reyes-Labarta and Marcilla. ${ }^{8}$ A scheme of six possible reactions is suggested and rate constants were calculated by a numerical simulation predicting the thermal gravimetric analysis data. It was shown that the higher the particle size of ADC, the higher was the overall reaction rate.

The plasticizers used in plastisol preparation affected the decomposition of ADC in plastisols., ${ }^{9,10}$ ADC decomposes within a polymeric matrix that presents resistance to the growth of the bubbles. The melt strength plays an important role in the process. 
The higher the molecular weight of the plasticizer the higher is the maximum temperature of the process corresponding to ADC decomposition. Foam density and elasticity of plastisols prepared from six different plasticizers and their mixtures were investigated by Velickovic et al. ${ }^{11}$ The expansion degree of the foam was related to the gelation temperature of the plastisols. If the gas expansion starts too early, part of the gas will be released before it could form a foam. ${ }^{11}$ There are numerical solutions to nucleating agent enhanced cell nucleation. ${ }^{12}$ Diffusivity solubility of the gas, surface tension, viscosity, and elasticity of the polymer melt are variables affecting sustainability of the bubbles formed. ${ }^{13}$ Plastisol dynamic mechanical analysis ${ }^{14}$ and thermomechanical analysis ${ }^{10}$ are used to study the gelation process of the plastisols.

This study was made in order to find out optimum gelation and foaming conditions for plastisols used in plastisol inks. Foamable plastisols with different colored pigments are in the market for printing on textiles. They are used by spreading on textiles as thin films and heating for gelation and foaming. For this purpose thin films of plastisols having only PVC, dioctyl phthalate (DOP), heat stabilizers, ADC, and zinc oxide were prepared in analogy to plastisol ink application, and their gelation, foaming, and dehydrochlorination behavior were investigated. Zinc oxide activator was used in all ADC decomposition and plastisol foaming studies. ${ }^{7-}$ ${ }^{11}$ However, there is no study on the effect of $\mathrm{ZnO}$ on the density, tensile strength, elasticity, and thermal stability of the foamed products. Thus, it was aimed to investigate the utilization of $\mathrm{ZnO}$ as an ADC activator agent, and examine the effects on mechanical properties and thermal stabilization in the present study.

The thermal gravimetric analysis of ADC and its mixture with $\mathrm{ZnO}$ were made to see the catalytic effect. PVC plastisol films with or without $\mathrm{ZnO}$ additive were subjected to varying periods of heating at $190^{\circ} \mathrm{C}$ and were characterized.

\section{MATERIALS AND METHODS}

\section{Materials}

Emulsion type PVC (Petvinil, E 38/74) (PVC) from PETKIM, Turkey, was used in the experiments. A detailed characterization of PVC was published in a previous study. ${ }^{15}$ Plasticizer dioctyl phthalate (DOP) and chemical blowing agent azodicarbonamide (ADC) from Merck, zinc stearate $\left(\mathrm{ZnSt}_{2}\right)$ and calcium stearate $\left(\mathrm{CaSt}_{2}\right)$ heat stabilizers from Baerlocher Co., and $\mathrm{ZnO}$ nucleation agent from Ege Kimya were used in the experiments.

\section{Preparation of the PVC foam films}

In order to produce PVC foam films, a PVC plastisol was prepared by mixing 80 parts of DOP and two parts of ADC as the chemical blowing agent to 100 parts emulsion PVC. After one part $\mathrm{CaSt}_{2}$ and one part $\mathrm{ZnSt}_{2}$ heat stabilizers and 2.5 parts $\mathrm{ZnO}$ as the catalyst were added, this emulsion was stirred until it became homogeneous. Thus a plastisol with $43 \mathrm{wt}$ $\%$ DOP was obtained. The plastisol was cast onto 10 $\times 24 \mathrm{~cm}$ glass substrate with the aid of an automatic film applicator with $90 \mu \mathrm{m}$ gap size (Sheen Instrument Ltd., model number: $1133 \mathrm{~N}$ ) at a speed of 150 $\mathrm{mm} / \mathrm{sec}$. Films were allowed to foam in oven at $190^{\circ} \mathrm{C}$ for different periods of 3, 6, 12, $24 \mathrm{~min}$ to see the effect of heating time on the foaming. Same experiments were done for samples without $\mathrm{ZnO}$.

\section{Dynamics of gelation of plastisol and foaming}

The gelation and foaming behavior of a thin film of plastisol having zinc oxide on a microscope slide was determined using the transmission optical microscope (Olympus, $\mathrm{CH} 40$ ) with a heated hot stage controlled by a temperature controller (Instec, STC 200C). The samples were heated at $5^{\circ} \mathrm{C} / \mathrm{min}$ rate from room temperature up to $190^{\circ} \mathrm{C}$ and kept at that temperature for $10 \mathrm{~min}$. The photographs were taken with Camedia Master Olympus Digital camera.

\section{Characterization of films}

Scanning electron microscopy (Philips XL-305 FEGSEM) was used to obtain PVC plastisol foam films cell structures, view the internal configuration of the cells, and measure the thickness of PVC plastisol foam films which were heated at $190^{\circ} \mathrm{C}$ for different time periods. SEM photographs of the gold coated fracture surface of samples obtained by tensile testing were taken for this purpose. Raw materials ADC and PVC were also characterized by SEM.

PVC plastisol foam films were heated for varying durations and the effect of the heating time on density, thickness; porosity and mechanical properties were investigated using Archimedes' apparatus, electronic digital caliper, and tensile testing machine, respectively. Density, pore volume, interconnectivity, and porosity were calculated using Archimedes method for five samples from each set by taking the water density as $0.997 \mathrm{~g} / \mathrm{cm}^{3}$ at $25^{\circ} \mathrm{C}$.

Tensile testing of the films were done according to ASTM D882. Stress-strain diagrams for samples with $\mathrm{ZnO}$ and without $\mathrm{ZnO}$ were obtained by tensile testing using Testometric tensile testing machine. Five samples from each set were cut to thin strips $10 \times$ $100 \mathrm{~mm}$ in size and stretched uniaxially with a cross-head speed of $10 \mathrm{~mm} / \mathrm{min}$. 


\section{Thermal stability of the films}

Kinetic studies of dehydrochlorination at $190^{\circ} \mathrm{C}$ were done to determine degradation of PVC foam film by using Metrohm 763 PVC Thermomat device. Thermal stability tests were done for PVC powder and for PVC foams heated for $3 \mathrm{~min}$ according to ISO 182-3.

The $0.5 \mathrm{~g}$ of PVC foam samples were cut into pieces with $0.5 \times 0.5 \mathrm{~cm}$ dimensions and they were put into a reaction vessel of PVC Thermomat. The reaction vessels that contained PVC plastigel films were placed into the heating blocks previously heated to $190^{\circ} \mathrm{C}$. $\mathrm{HCl}$ formed was removed by a nitrogen gas stream and transferred into the measuring vessels filled with deionized water. Water absorbed $\mathrm{HCl}$ gas and the change in the conductivity of the solution was measured with respect to time by a conductimeter. Thus, the decomposition process was monitored by measuring the conductivity of the aqueous $\mathrm{HCl}$ solution.

The time period when the conductivity starts to increase is called as induction time, and the time period when the conductivity value reaches to $50 \mu \mathrm{S} /$ $\mathrm{cm}$ is called as stability time. This value is the maximum acceptable level of degradation.

\section{Thermal gravimetric analysis (TGA)}

TGA analyses were performed by Perkin Elmer Diamond TG/DTA. Pure ADC and an ADC-ZnO (1: 1 weight ratio) mixtures were prepared prior to the TGA analysis. A small amount of powder was filled in an aluminum pan for each run and analysis were carried out at temperature range from 29 to $300^{\circ} \mathrm{C}$ increasing $10^{\circ} \mathrm{C} / \mathrm{min}$ under $20 \mathrm{~cm}^{3} / \mathrm{min}$ nitrogen gas flow.

\section{RESULTS AND DISCUSSION}

Catalytic effect of $\mathrm{ZnO}$ on ADC decomposition was studied by thermal gravimetric analysis.

\section{Decomposition of ADC and ADC-ZnO mixture}

In this study, ADC decomposition behavior was studied by thermal gravimetric analysis (TGA) to observe its degradation kinetics. Combined mass loss curves of ADC and ADC : $\mathrm{ZnO}$ mixture (1: 1 weight ratio) are shown in Figure 1.

$\mathrm{N}_{2}$ and $\mathrm{CO}$ are the gaseous products of ADC and its solid residue consists of urazol and hydroazodicarbonamid. ${ }^{3} \mathrm{ZnO}$ has two effects on ADC decomposition. Lowering the decomposition onset temperature and leading to complete gasification of ADC. $\mathrm{ZnO}$ decreased the ADC decomposition onset temperature nearly $20^{\circ} \mathrm{C}$ from $200^{\circ} \mathrm{C}$ to $180^{\circ} \mathrm{C}$ as seen in

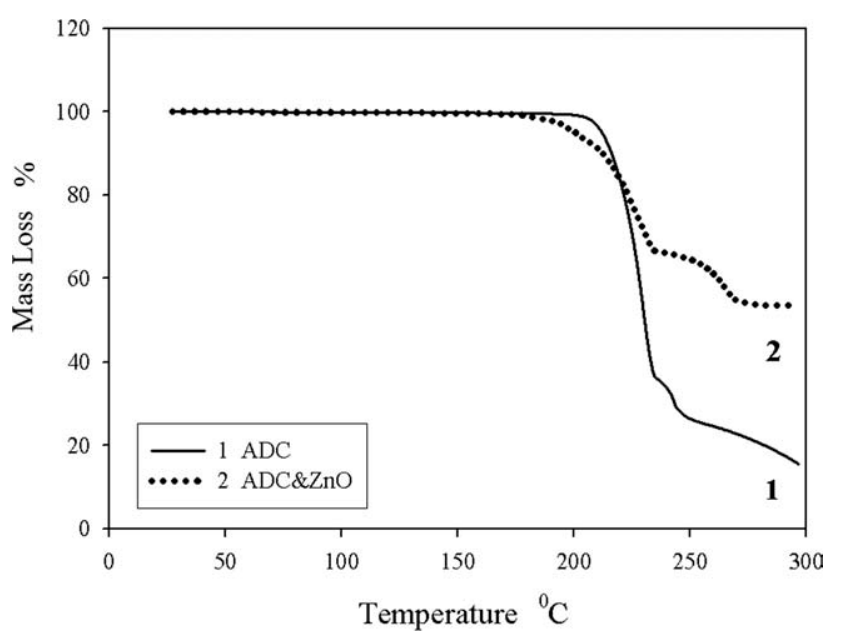

Figure 1 TGA curves of (1) pure ADC and (2) $1: 1$ mass ratio $\mathrm{ADC}-\mathrm{ZnO}$ mixture.

Figure 1. The solid residue at $300^{\circ} \mathrm{C}$ from decomposition of pure ADC is $15 \%$. Pure $\mathrm{ZnO}$ does not decompose at all up to $300^{\circ} \mathrm{C}$ and for the $1: 1 \mathrm{mix}-$ ture $50 \%$ of the mass should remain at this temperature if all ADC decomposes. Indeed, $50 \%$ of total mass remained for $1: 1$ mass ratio mixture of ADC : $\mathrm{ZnO}$ indicating total decomposition of ADC. $\mathrm{ZnO}$ affected ADC decomposition, leading to complete gasification of ADC.

\section{Simultaneous processes that occur on heating plastisol films}

During heating of plastisols at $190^{\circ} \mathrm{C}$ the following processes occur

a. Plasticizer DOP diffuses in PVC particles.

b. PVC particles are swollen by the diffused plasticizer and the swollen particles fuse each other forming a plastic mass.

c. During fusion process crosslinking of PVC molecules occur by the effect of heat.

d. ADC decomposes to give gases and solid products.

e. The evolved gases nucleate at the surfaces of $\mathrm{ZnO}$ nucleation centers.

f. The gases expand around the nucleation centers and they are entrapped in fused and crosslinked plasticized mass.

g. PVC dehydrochlorinates give conjugated double bonds and cause discoloration.

Thus an optimum heating period should be determined that will allow sufficient decomposition of $\mathrm{ADC}$ and sufficient gelation and fusion of plastisol to entrap the released gases without detrimental dehydrochlorination of PVC.

The optical micrographs in Figure 2 show the dynamics of gelation and fusion of the plastisols and 


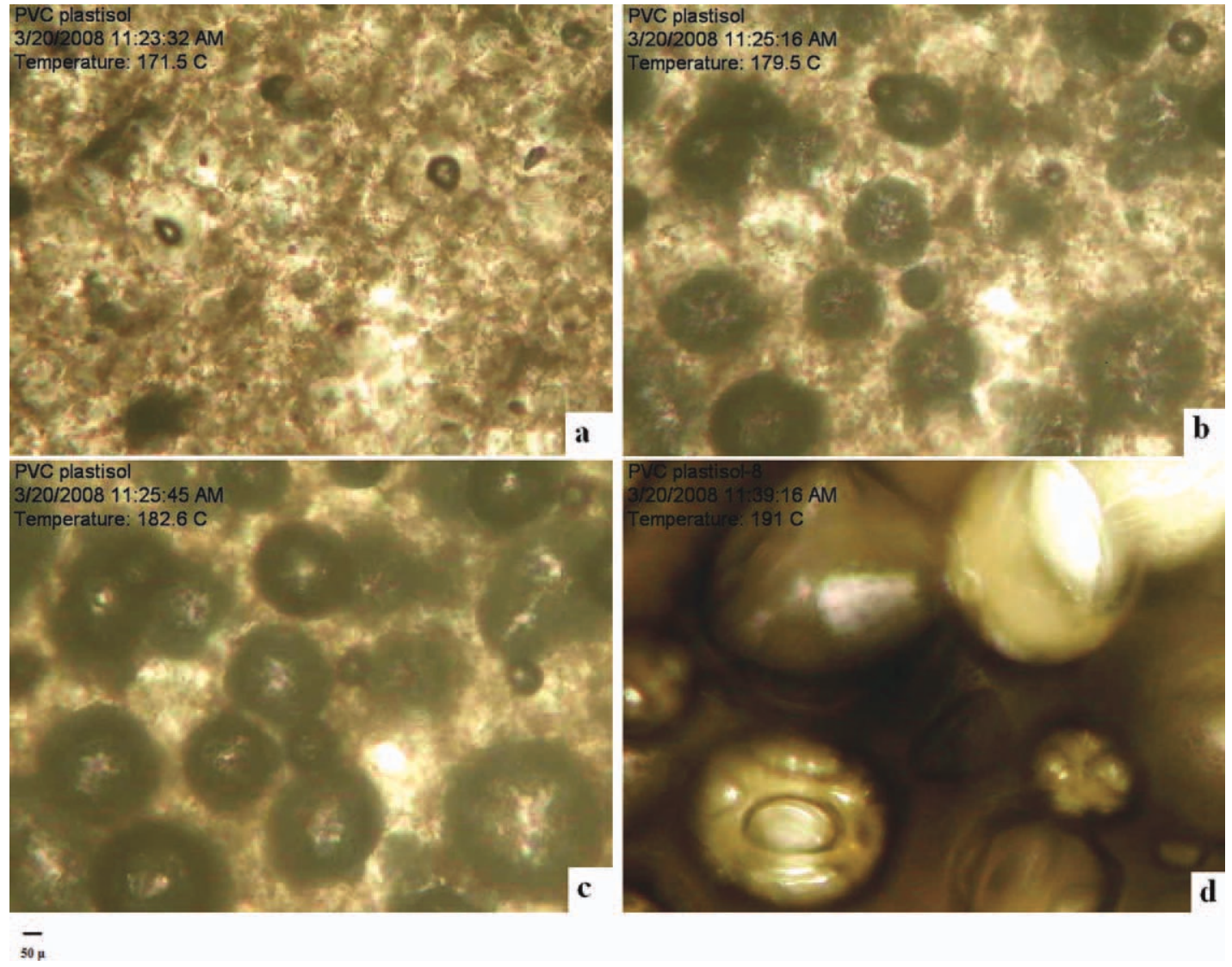

Figure 2 Optical micrographs of plastisols on programmed heating at $5^{\circ} \mathrm{C} / \mathrm{min}$ rate and taken at (a) $171.5^{\circ} \mathrm{C}$, (b) $179.5^{\circ} \mathrm{C}$, (c) $182.6^{\circ} \mathrm{C}$ and (d) after heating at $190^{\circ} \mathrm{C}$ for $10 \mathrm{~min}$. [Color figure can be viewed in the online issue, which is available at wileyonlinelibrary.com.]

the foaming process as a function of temperature. At $171.5^{\circ} \mathrm{C}$ the PVC particles were present as different entities. As heating temperature and time increased the individual particles disappear and after heating for $10 \mathrm{~min}$ at $191^{\circ} \mathrm{C}$ a plastic mass was present. The plasticizer and PVC particles could not be distinguished from each other at this temperature as observed by Jourdan and Owen. ${ }^{16}$ The foam nucleation and growth started at $171.5^{\circ} \mathrm{C}$. As the temperature increased the diameter of the foams increased and reached to $150 \mu \mathrm{m}$ average size at $190^{\circ} \mathrm{C}$. In heating plastisol films on a hot stage, heat transfer is from one direction only. Since the films were very thin, it was assumed that the films are in thermal equilibrium with the hot stage.

\section{Plastisol components morphology}

Figure 3 shows the SEM micrograph of PVC and azodicarbonamide. In Figure 3(a), it is seen that azodicarbonamide had 1-9 $\mu \mathrm{m}$ crystals, and in Figure $3(b)$, it is seen that PVC particles are spherical and have 1-20 $\mu \mathrm{m}$ diameter. PVC and ADC particles were dispersed in plasticizer DOP forming a plastisol.

\section{Morphology of gelled and foamed films}

In Figure 4, SEM micrographs of PVC plastisol foam films heated for different period of times at $190^{\circ} \mathrm{C}$ in an oven are shown. Approximate thickness values of samples were measured by SEM analysis. The film which was heated for 3 min had 345-382 $\mu \mathrm{m}$ thickness as seen in Figure 4(a). Even at 3 min heating period some pores were formed. The thickness of film heated for $6 \mathrm{~min}$ was $392-400 \mu \mathrm{m}$ as seen in Figure 4(b). Since an automatic film applicator with $90 \mu \mathrm{m}$ gap size was used in film preparation, the film was expanded in volume during this short heating period. However, Figure 4(c) shows that the thickness of the 12 min heated film was increased to 1-1.15 mm. The thickness of film heated for $24 \mathrm{~min}$ was $1.12-1.2 \mathrm{~mm}$ as seen in Figure 4(d). It is concluded from this figure that thickness of the film was increased when the heating time was increased at the same temperature.

In these samples, the formation of closed pores are nonuniform and they have a broad size distribution. However, the internal configuration of the cells is much ordered in Figure $4(\mathrm{c}, \mathrm{d})$, since pore formation was completed. The pores are ellipsoidal in shape since their expansion in lateral direction is 

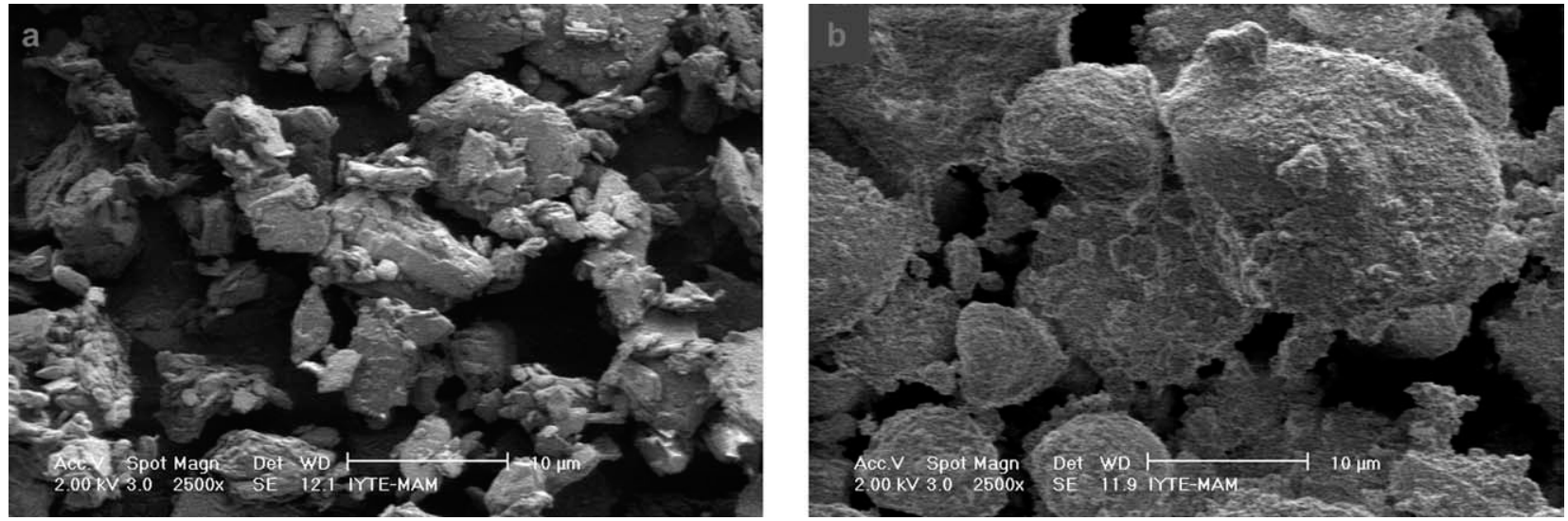

Figure 3 SEM micrographs of (a) azodicorbonamide and (b) PVC powders.

more restricted compared to the vertical direction. The average size of pores in the completely foamed samples is around $150 \mu \mathrm{m}$ in the lateral direction and $300 \mu \mathrm{m}$ in the vertical direction.

\section{Density, pore volume and mechanical test}

Samples with $\mathrm{ZnO}$ and without $\mathrm{ZnO}$ were tested for density and porosity using Archimedes' apparatus and for mechanical properties using a uniaxial ten- sile testing machine. The results of the tests are reported in Tables I and II. As seen in Table I, the density, $\rho$, of the foam having $\mathrm{ZnO}$ gradually decreased from $1.17 \mathrm{~g} / \mathrm{cc}$ to $0.285 \mathrm{~g} / \mathrm{cc}$ with increasing heating time. The difference in density between the 6 and 12 min shows the completion of foam formation at this period. The average thickness of the samples and the average porosity again showed a consistent increase with heating time. Average porosity of $76 \%$ was obtained for the 12 -minute heated
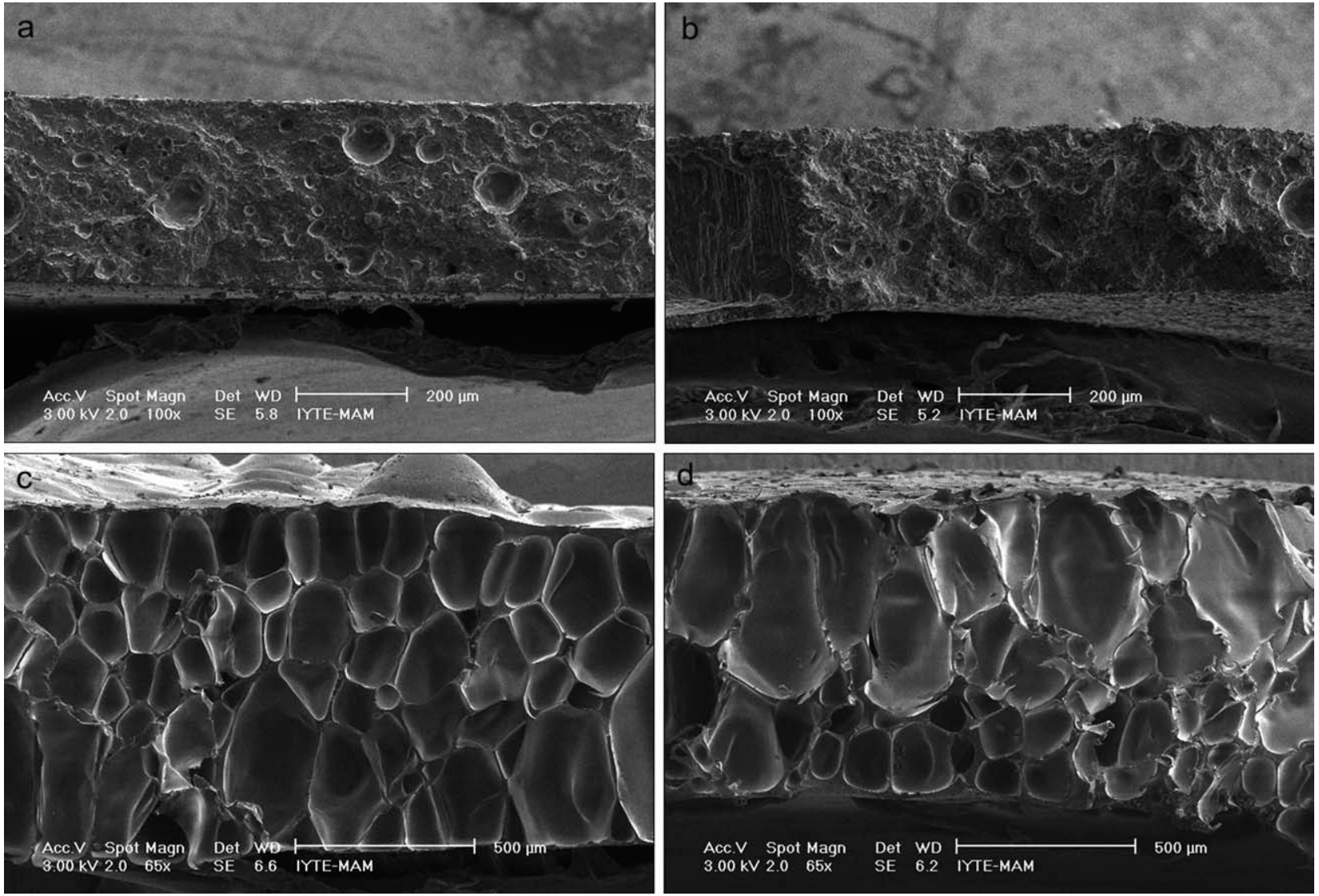

Figure 4 SEM micrograph of the PVC plastisol foam films cross-sections for heating (a) 3 min at $\times 100$ magnification, (b) $6 \mathrm{~min}$ at $\times 100$ magnification, (c) $12 \mathrm{~min}$ at $\times 65$ magnification, and (d) $24 \mathrm{~min}$ at $\times 65$ magnification at $190^{\circ} \mathrm{C}$. 
TABLE I

Thickness, Average Density, Average Pore Volume \% of the Films

\begin{tabular}{|c|c|c|c|c|c|c|}
\hline \multirow[b]{2}{*}{ Heating period (min) } & \multicolumn{2}{|c|}{ Average thickness (mm) } & \multicolumn{2}{|c|}{ Average density $\left(\mathrm{g} / \mathrm{cm}^{3}\right)$} & \multicolumn{2}{|c|}{ Average pore volume (\%) } \\
\hline & With $\mathrm{ZnO}$ & Without $\mathrm{ZnO}$ & With $\mathrm{ZnO}$ & Without $\mathrm{ZnO}$ & With $\mathrm{ZnO}$ & Without $\mathrm{ZnO}$ \\
\hline 3 & 0.35 & 0.11 & 1.17 & 1.20 & 2.9 & 0 \\
\hline 6 & 0.40 & 0.11 & 1.16 & 1.20 & 3.4 & 0 \\
\hline 12 & 1.10 & 0.11 & 0.29 & 1.20 & 75.8 & 0 \\
\hline 24 & 1.15 & - & 0.29 & - & 76.2 & - \\
\hline
\end{tabular}

sample is consistent with the calculations for the ratio of the total gas evolution to the bulk volume of the polymer. During the preparation of PVC plastisol, two parts of ADC per 100 part PVC were used. Therefore, it is expected that approximately $400 \mathrm{~cm}^{3}$ of gas was released and caused blowing of the PVC films. ${ }^{7}$ Based on this fact, the average pore volume percentage has been calculated as $71 \%$ according to $1.2 \mathrm{~g} / \mathrm{cm}^{3}$ theoretical density of foam film. Therefore, it can be assumed that nearly all the released gas takes part in pore formation. Porosity of PVC plastisol without $\mathrm{ZnO}$ was determined as zero due to lack of foaming at $190^{\circ} \mathrm{C}$.

As seen in Table II, the average tensile strength of the foams with $\mathrm{ZnO}$ increased from 0.43 to $0.98 \mathrm{MPa}$ with prolonged heating. The data show that simultaneous gelation and foam formation occur during heating of the films. According to the fracture mechanics theory of open cell foams, the tensile strength is inversely proportional to the average diameter of pores. If only foaming would occur the tensile stregth would be lowered with heating time. Moreover, the tensile strength of PVC foams is reported to decrease with reduction in density. ${ }^{17}$ PVC foam is a composite material having plasticized polymer as the matrix phase and gas filled pores as the dispersed phase. According to equal assumption of the slab model, the tensile strength $\left(\sigma_{C}\right)$ of a composite equals to ${ }^{18}$

$$
\sigma_{C}=\varphi_{P} \sigma_{P}+\varphi_{F} \sigma_{F}
$$

Thus, tensile strength $\sigma_{F}$ of the filler, pores in the present case was taken as zero, and $\sigma_{P}$ was taken as the measured tensile strength of the plastic phase to predict the tensile strength of the composites.
Elastic modulus of the foams can be predicted using elastic modulus of the plastic phase and ratio of the densities of the foam $(\rho)$ to the plastic $\left(\rho_{p}\right)^{19}$

$$
E_{C}=E_{p}\left(\rho / \rho_{p}\right)^{2} .
$$

The tensile strength and elastic modulus were predicted from eqs. (2) and (3), respectively, for $\mathrm{ZnO}$ containing films and were shown in Table II. It is reasonable to take the properties of samples without $\mathrm{ZnO}$ as the theoretical properties for dense PVC and compare the theoretical composite properties obtained from eqs. 2 and 3 to the experimental data given in Table II. Theoretically the ratio of tensile strength of different samples are proportional to the ratio of their polymer fractions. However, the inverse trend observed in the samples is due to the increase of tensile strength with prolonged heat treatment by gelation and crosslinking of the polymer as seen in Table II. The same effect is observed in Table II as the ductility of the foams and elongation at break increased nearly 10 times with increased heating times. The decrease of modulus also is an indication of the effect of gelation step on mechanical properties. In a similar study by Baltacioglu and Balköse, ${ }^{6}$ it was observed that gelation is a function of temperature and time and so are mechanical properties. It was shown that at $140^{\circ} \mathrm{C}$ complete gelation is achieved at $45 \mathrm{~min}$. After this heating time, a negligibly small change was observed in the tensile strength and strain of flexible PVC with $60 \%$ dioctyl phthalate and $\mathrm{ZnSt}_{2}$. A similar behavior was observed as shown in Table II as a plateau in tensile strength and strain was present above the heating time of $12 \mathrm{~min}$. This observation suggested that the gelation was completed in

TABLE II

\begin{tabular}{|c|c|c|c|c|c|c|c|c|}
\hline \multirow[b]{2}{*}{$\begin{array}{l}\text { Heating period at } \\
190^{\circ} \mathrm{C}(\mathrm{min})\end{array}$} & \multicolumn{3}{|c|}{ Tensile strength (MPa) } & \multicolumn{2}{|c|}{ Strain at break $(\%)$} & \multicolumn{3}{|c|}{ Elastic modulus (MPa) } \\
\hline & $\begin{array}{l}\text { Predicted } \\
\text { with } \mathrm{ZnO}\end{array}$ & $\begin{array}{l}\text { Experimental } \\
\text { with } \mathrm{ZnO}\end{array}$ & $\begin{array}{l}\text { Without } \\
\text { ZnO }\end{array}$ & $\begin{array}{l}\text { With } \\
\mathrm{ZnO}\end{array}$ & $\begin{array}{l}\text { Without } \\
\mathrm{ZnO}\end{array}$ & $\begin{array}{l}\text { Predicted } \\
\text { with } \mathrm{ZnO}\end{array}$ & $\begin{array}{l}\text { With } \\
\mathrm{ZnO}\end{array}$ & $\begin{array}{c}\text { Without } \\
\text { ZnO }\end{array}$ \\
\hline 3 & 0.49 & 0.43 & 0.50 & 15.82 & 13.21 & 5.80 & 3.65 & 6.10 \\
\hline 6 & 1.35 & 0.79 & 1.40 & 19.04 & 33.10 & 4.32 & 4.70 & 4.62 \\
\hline 12 & 1.33 & 0.98 & 5.50 & 207.53 & 203.47 & 0.24 & 0.68 & 4.07 \\
\hline 24 & - & 0.98 & - & 205.81 & - & - & 0.69 & - \\
\hline
\end{tabular}

Predicted and Experimental Mechanical Properties of Samples With and Without ZnO 
less than $12 \mathrm{~min}$ for this composition at $190^{\circ} \mathrm{C}$. On the other hand, foaming due to ADC decomposition is a continuous process starting at the start of heating and completing at the same time period with gelation.

Completion of gelation in $12 \mathrm{~min}$ at $190^{\circ} \mathrm{C}$ was also supported by data obtained from samples without $\mathrm{ZnO}$. The mechanical properties for 3, 6, and 12 min heated PVC plastisols without $\mathrm{ZnO}$ are also shown in Table II. The 24 min heated sample was not suitable for mechanical testing due to thermal degradation. As evident from the values, composite theory applies well for the low porosity PVC foams and there is no linear variation in the strength and modulus with increasing porosity. This may be due to the effect of $\mathrm{ZnO}$ on gelation. Samples without $\mathrm{ZnO}$ does not foam at $190^{\circ} \mathrm{C}$ as evident from zero porosity measured using Archimedes' apparatus. Relatively higher modulus and tensile strength in samples without $\mathrm{ZnO}$ can be attributed to the lack of pore formation.

\section{Thermal stability of the films}

Induction time and stability time of pure PVC powder and PVC foam film were determined from Figure 5 and are reported in Table III. PVC dehydrochlorination at high temperature has been reduced by addition of the $\mathrm{ZnSt}_{2}$ and $\mathrm{CaSt}_{2}$ heat stabilizers. Reaction of these stabilizers with $\mathrm{HCl}$ greatly reduces the autoaccelerating effect of $\mathrm{HCl}$ released by dehydrochlorination. Previous studies have indicated that PVC including metal soap interacts with $\mathrm{HCl}$ and decreases its degradation effect as seen in eqs. (5) and (6). $\mathrm{ZnSt}_{2}$ and $\mathrm{CaSt}_{2}$ were used together because of their synergetic effect that was shown by Balkose

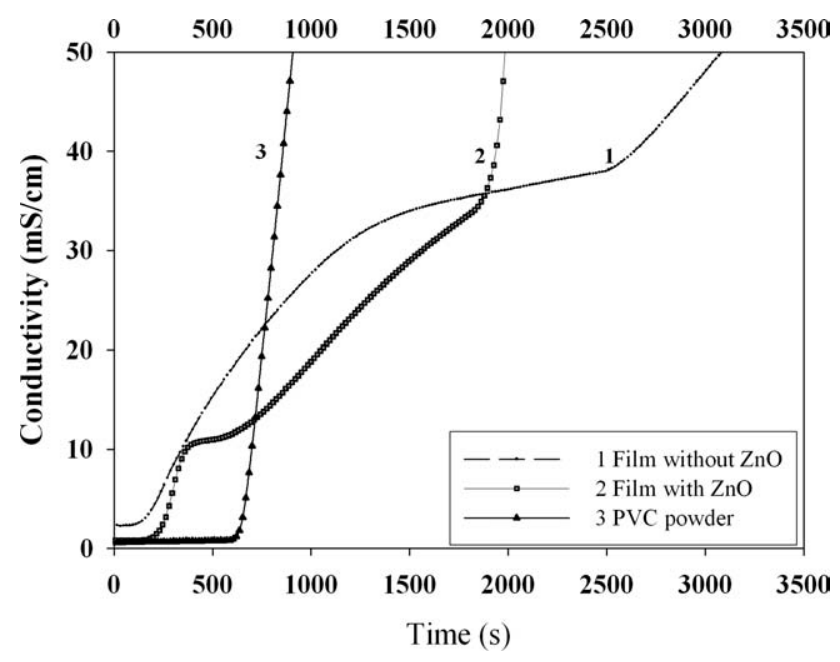

Figure 5 The change of conductivity of the aqueous solution due to hydrogen chloride release from (1) pure PVC powder, (2) PVC Film with $\mathrm{ZnO}$ initially heated at $190^{\circ} \mathrm{C}$ for $3 \mathrm{~min}$, and (3) PVC film without ZnO initially heated at $190^{\circ} \mathrm{C}$ for $3 \mathrm{~min}$.
TABLE III

Induction and Stabilization Time Values at $190^{\circ} \mathrm{C}$ for Pure PVC and PVC Foam Films in PVC Thermomat Tests

\begin{tabular}{lcc}
\hline Sample & $\begin{array}{c}\text { Induction } \\
\text { time (min) }\end{array}$ & $\begin{array}{c}\text { Stability } \\
\text { time (min) }\end{array}$ \\
\hline PVC & 11.0 & 15.0 \\
PVC film with ZnO & 3.6 & 30.6 \\
PVC film without ZnO & 3.0 & 51.5 \\
\hline
\end{tabular}

et al. ${ }^{4}$ The $\mathrm{ZnCl}_{2}$ formed by reaction of $\mathrm{ZnSt}_{2}$ with $\mathrm{HCl}$ had also an accelerating effect on dehydrochlorination reaction. Thus, it was converted to inactive products by reacting with $\mathrm{CaSt}_{2}$ as shown by eq. (6)

$$
\begin{aligned}
\mathrm{ZnSt}_{2}+2 \mathrm{HCl} & \rightarrow \mathrm{ZnCl}_{2}+2 \mathrm{HSt}, \\
\mathrm{CaSt}_{2}+\mathrm{ZnCl}_{2} & \rightarrow \mathrm{CaCl}_{2}+\mathrm{ZnSt}_{2},
\end{aligned}
$$

Induction times for PVC film with $\mathrm{ZnO}$ (3.6 min) and without $\mathrm{ZnO}(3.0 \mathrm{~min})$ were lower than that of pure PVC (11 $\mathrm{min})$. On the other hand, the stability times (30.6 and $51.5 \mathrm{~min}$ ) were much longer than that of pure PVC (15 min).

$\mathrm{ZnO}$ is capable of neutralizing $\mathrm{HCl}$ forming $\mathrm{ZnCl}_{2}$ as shown in eq. (6).

$$
\mathrm{ZnO}+2 \mathrm{HCl} \rightarrow \mathrm{ZnCl}_{2}+\mathrm{H}_{2} \mathrm{O} .
$$

On the other hand, it is a well known fact that when $\mathrm{ZnCl}_{2}$ concentration exceeds a certain level, it also accelerates dehydrochlorination reaction extensively. Thus, films with $\mathrm{ZnO}$ degrade at a very high rate after $1700 \mathrm{sec}(28.3 \mathrm{~min})$ as seen in Figure 5. In the time period of $12 \mathrm{~min}$ required for foaming and gelation of the films in the present study, degradation of PVC was at an acceptable level for both films with and without $\mathrm{ZnO}$. Compared to $10 \mathrm{~min}$ heating time at $220^{\circ} \mathrm{C}$ used in previous studies for PVC-co-PVAC plastisols made by other workers ${ }^{10}$ the gelation and foaming period of $12 \mathrm{~min}$ at $190^{\circ} \mathrm{C}$ is an acceptable value for producing thin films of flexible PVC foam.

\section{CONCLUSION}

$\mathrm{ZnO}$ catalytic effect on ADC decomposition has been obtained by TGA analysis. $\mathrm{ZnO}$ can be used in PVC foam formation to decrease activation energy of the $\mathrm{ADC}$ decomposition reaction because; presence of $\mathrm{ZnO}$ decreases the onset of $\mathrm{ADC}$ decomposition temperature nearly $20^{\circ} \mathrm{C}$.

Gelation of PVC plastisol and pore formation was completed in $12 \mathrm{~min}$ for samples with $\mathrm{ZnO}$ as shown by tensile tests and porosity evolution. Density, porosity, and mechanical properties were measured as a function of heating time and average porosity shows a consistent increase with heating time 
up to $76 \%$ and the average density decreased from 1.170 to $0.285 \mathrm{~g} / \mathrm{cm}^{3}$ for the samples containing $\mathrm{ZnO}$. Tensile test shows that the tensile strength and tensile strain both increased considerably with heating time up to $0.98 \mathrm{MPa}$ and $207 \%$, respectively, for samples with $\mathrm{ZnO}$ and $5.5 \mathrm{MPa}, 203 \%$ for samples without $\mathrm{ZnO}$. On the other hand, the elastic modulus was seen to gradually decrease with heating time for both samples. This deformation behavior of PVC foam film is an indication of two simultaneous processes taking place during heating: gelation and pore formation. The data obtained for elastic modulus and tensile strength cannot be fully explained by the composite theory because of the two opposing effects on the tensile strength. The tensile strength increases with gelation and decreases with foaming. The small change observed in mechanical properties after 12 min suggests that gelation and foaming was completed less than $12 \mathrm{~min}$ at $190^{\circ} \mathrm{C}$. Average pore volume percent calculations also proved that all the released gas coming from ADC decomposition was held in the foam film; 12 min heated foam film average experimental and theoretical pore volume percent were close to each other as $76 \%$ and $71 \%$, respectively.

In the time period of $12 \mathrm{~min}$ required for complete foaming and gelation of the films in the present study, degradation of PVC was at an acceptable level both for films with and without $\mathrm{ZnO}$.

The authors thank I. Akcok, B. Kanbar, and N. Kiymet for their contribution to the experimental work in this study.

\section{References}

1. Demir, H.; Sipahioglu, M.; Balköse, D.; Ülkü, S. J Mater Process Technol 2008, 195, 144.

2. Azimipour, B.; Marchand, F. J Vinyl Additive Technol 2006, $12,55$.

3. Garcia, J. C.; Marcilla, A. Polymer 1998, 39, 3507.

4. Balköse, D.; Gökçel, İ. H.; Göktepe, E. S. Eur Polym J 2001, 37, 1191.

5. Atakul, S.; Balkose, D.; Ulku, S. J Vinyl Additive Technol 2005, 11, 47

6. Baltacioglu, H.; Balkose, D. J Appl Polym Sci 1999, 74, 2488.

7. Reyes-Labarta, J. A.; Olaya, M. M.; Marcilla, A. J Appl Polym Sci 2006, 102, 2015.

8. Reyes-Labarta, J. A.; Marcilla, A. J Appl Polym Sci 2008, 107, 339.

9. Reyes-Labarta, J. A.; Marcilla, A. J Appl Polym Sci 2007, 107, 339.

10. Zoller, A.; Marcilla, A. Appl Polym Sci 2011, 121, 3314.

11. Velickovic, S. J.; Strakov, D.; Popovic, I. G.; Brankov, L.; Cvarkov, L. J Vinyl Additive Technol 2002, 8, 159.

12. Wang, C.; Leung, S. N.; Bussmann, M.; Zhai, W. T.; Park, C. B. Ind Eng Chem Res 2010, 49, 12783.

13. Leung S. N. S. Mechanism of Cell Nucleation, Growth, and Coarsaning in Plastic Foaming: Theory, Simulation, and Experiment, Ph.D. Thesis, University of Toranto. Available at: https://tspace. library.utoronto.ca/.../Leung_Siu_NS_200911_PhD_thesis.pdf

14. Daniels, P. H. J Vinyl Additive Technol 2007, 13, 151.

15. Savrik, S. A.; Balkose, D.; Ulutan, S.; Ulku, S. Therm Anal Calorim 2010, 101, 801

16. Jourdan, J. S.; Owen, D. P. J Vinyl Additive Technol 2008, 14, 99.

17. Patterson, J. J Vinyl Additive Technol 1998, 4, 26.

18. Crawford, R. J. Plastic Engineering; Pergamon Press: New York, 1981.

19. Alian, A. M.; Abu-Zahra, N. Polym Plast Technol Eng 2009, $48,1014$. 